\title{
Long-term effects of peatland black spruce regeneration treatments in northeastern Ontario
}

\author{
by Arthur Groot ${ }^{1}$ and Michael J. Adams ${ }^{2}$
}

\begin{abstract}
Studies of black spruce (Picea mariana (M ill.) BSP) broadcast seeding and of harvest methods for advance regeneration protection were remeasured 17 to 20 years after establishment on peatland sites in northeastern Ontario. The effects of seeding rate on black spruce stocking, density or basal area were apparent at two study locations 20 years after treatment, but high levels of advance regeneration masked seeding rate effects at two other study locations. The effects of different harvest methods on black spruce stocking, density and basal area, which were evident at earlier ages, were no longer statistically significant 17 to 19 years after treatment. Black spruce density increased moderately with time because of gradual recruitment of new seedlings. Density of black spruce stems taller than $1.3 \mathrm{~m}$ tall exceeded $4000 \mathrm{ha}^{-1}$ for nearly all treatments, but these stems were spatially aggregated at the $4-\mathrm{m}^{2}$ scale. The stand characteristics of these regenerated peatland stands are consistent with site class 2 stands in the Ontario normal yield tables.
\end{abstract}

Key words: black spruce; Picea mariana; advance regeneration; direct seeding; regeneration; peatland; stand dynamics

\section{RÉSUMÉ}

Les études sur l'ensemencement à la volée ainsi que des méthodes de récolte avec protection de la régénération préexistante d'épinette noire (Picea mariana (M ill.) BSP) ont fait l'objet d'un remesurage 17 à 20 ans après la régénération sur des stations humides du nord-est de l'Ontario. Les effets du taux d'ensemencement sur le nombre de tiges à l'hectare d'épinette noire, de la densité ou de la surface terrière étaient apparents sur deux stations étudiées, 20 ans après le traitement, mais les taux élevés de régénération préexistanteont masquéles effets du taux d'ensemencement dans le cas de deux autres stations. Les effets de différentes méthodes de récolte sur le taux de tiges à l'hectare, la densité et la surface terrière d'épinette noire qui étaient évidents à un âge précoce, n'étaient plus statistiquement significatifs 17 à 19 ans après le traitement. La densité de l'épinette noire a diminué de façon modérée en fonction du temps suite à l'apparition graduelle de recrues provenant de nouveaux semis. La densité des tiges d'épinette noire de plus de 1,3 $\mathrm{m}$ de hauteur dépassait les 4000 tiges ha-1 $^{-1}$ dans presque tous les traitements, mais ces tiges étaient spatialement regroupées selon une échelle de 4- $\mathrm{m}^{2}$. Les caractéristiques de ces peuplements régénérés sur sol humide correspondaient aux peuplements de station de classe 2 des tables de rendement normal del'Ontario.

Mots clés : épinette noire, Picea mariana, régénération préexistante, ensemencement direct, tourbière, dynamique des peuplements

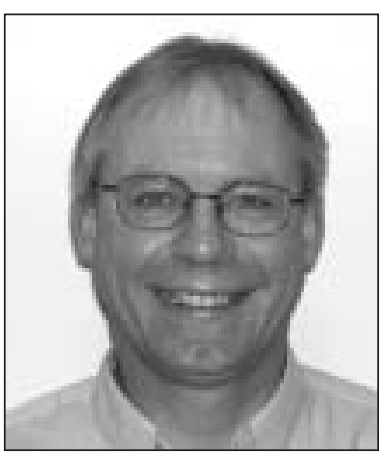

Arthur Groot

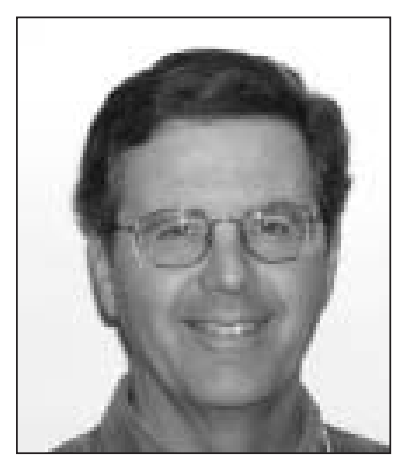

Michael J . Adams

\footnotetext{
${ }^{1}$ Natural Resources Canada, Canadian Forest Service, Great Lakes Forestry Centre, 1219 Queen St. E., Sault Ste. Marie, Ontario P6A 2E5. E-mail: agroot@nrcan.gc.ca (Corresponding author) ${ }^{2}$ Natural Resources Canada, Canadian Forest Service, Great Lakes Forestry Centre, 1219 Queen St. E., Sault Ste. Marie, Ontario P6A $2 \mathrm{E} 5$.
}

\section{Introduction}

Inadequate regeneration of black spruce on clear-cuts was considered a major problem in black spruce management in Ontario during the 1970s (M arek 1975, Fraser et al. 1976). Destruction of advance regeneration, lack of residual seedbearing trees and lack of suitable seedbed all contributed to low levels of natural regeneration on many harvest areas (Groot et al. 2001). These deficiencies prompted additional research by the Canadian Forest Service on the regeneration of black spruce, including experiments initiated in the early 1980s to study regeneration of peatland sites in northeastern Ontario.

Direct seeding of jack pine was being carried out successfully on a large scale at this time (Fleming et al. 2001), and it was thought that the technique might be extended to black spruce. To obtain information on the types and amounts of seedbed and the seeding rates required for success, seeding experiments were established during 1982-1984 at four locations in northeastern Ontario (Groot and Adams 1994).

At the sametime, changes in forest harvesting equipment and techniques were increasing the feasibility of protecting advance regeneration during mechanized harvest operations. A study was initiated during 1982-1984 to compare 
the ability of three harvest methods to protect black spruce advance regeneration (Groot 1987), often abundant on peatland sites (Groot 1984).

Remeasurements of these studies were carried out on several occasions (Groot 1987, 1995, 1996a, 1996b; Groot and Adams 1994), most recently 17 to 20 growing seasons after study establishment. These data afford an opportunity to answer the following questions: (i) are the effects of black spruce broadcast seeding and advance regeneration protection treatments detectable after two decades? (ii) what are the dynamics of black spruce regeneration on peatland sites?

\section{Methods}

\section{Broadcast seeding study}

A black spruce seeding study was established at four locations within the Northern Clay Section of the Boreal Forest Region (Rowe 1972) during 1982-1984 (Groot and Adams 1994). The original forest at all locations was dominated by black spruce, and the predominant ecosites represented were ES11 (Black Spruce- Labrador-tea - Organic Soil) and ES12 (Black Spruce - Larch - Labrador-tea - Organic Soil) (Taylor et al. 2000). Peat depths generally ranged from 50 to $200 \mathrm{~cm}$. At all locations, the forests were harvested by clearcutting, and winter shearblading was used for site preparation. The aim of shearblading was to remove surface layers of moss and peat in corridors 2.5 to $4 \mathrm{~m}$ wide.

As part of the study, broadcast seeding was carried out on 20-m $\times 20-\mathrm{m}$ or 30-m $\times 30-\mathrm{m}$ plots using a hand-operated Cyclone ${ }^{\circledR}$ seeder at rates of $0,50,100$, and 150 thousand viable seeds ha-1. Each seeding rate was replicated three (two locations) or four times (two locations). Glyphosate herbicide was applied aerially (1.4 to $2.2 \mathrm{~kg}$ active ingredient $\mathrm{ha}^{-1}$ ) once at each location, from four to seven years after seeding, as part of operational programs to control competing vegetation (Groot 1996a). Black spruce regeneration was largely free of competition from broad-leaved species after these treatments.

Regeneration measurements were carried out after the second, fifth, tenth (Groot and Adams 1994, Groot 1996a), and, most recently, twentieth growing season. The height and species of each stem on permanently marked $4-\mathrm{m}^{2}$ quadrats ( 20 or 25 per plot) was recorded at each measurement occasion, and the diameter at breast height ( $\mathrm{dbh}$ ) of all stems taller than $1.3 \mathrm{~m}$ was additionally recorded during the twentieth-year remeasurement. It was possible to distinguish advance regeneration from trees established from seed until the tenth-year remeasurement, but this was no longer possible during the twentieth-year remeasurement.

\section{Protection of advance regeneration study}

A study was established during 1982-4 to compare the effect of three harvest methods on regeneration in black sprucedominated peatland stands (primarily ES11 and ES12 ecosites [Taylor et al. 2000]): (i) winter (tracked fellerbuncher and cable skidder in winter on three harvest blocks); (ii) summer wide (tracked feller-buncher and widetired cable skidder in summer on five harvest blocks); and (iii) summer narrow (manual chainsaw felling and narrowtired cable skidder in summer on three harvest blocks) (Groot 1987). The harvest blocks were situated about $60 \mathrm{~km}$ from the town of Kapuskasing, in the N orthern Clay Section of the Boreal Forest Region (Rowe 1972).
Thestudy blocks were located within operational harvest areas, and equipment operators were not apprised of the study. Because the study was conducted within an operational harvesting program, the harvest methods were not randomly assigned to study blocks. The study blocks were selected prior to harvest, using the following selection criteria: peatland site type; black spruce dominated-stands; and high levels of black spruce advance regeneration. Aerial application of 2,4-D (2.0 to $2.4 \mathrm{~kg}$ active ingredient ha- ${ }^{-1}$ ) was carried out on the winter and summer wide harvest blocks, from four to seven years after harvesting, as part of operational treatments to control competing vegetation (Groot 1996b). Black spruce regeneration in these treatments was largely free of competition from broad-leaved species after these treatments. Regeneration in the summer narrow harvest blocks did not require release from competing vegetation.

M easurements were carried out prior to harvest, and 1, 3, 6, and 10 years after harvest (Groot 1987, 1995, 1996b). All harvest blocks were remeasured in the fall of 2001, 17 to 19 growing seasons after harvest. The height and species of each stem on permanently marked transects of $4-\mathrm{m}^{2}$ quadrats was recorded at each re-measurement, and the diameter at breast height (dbh) was additionally recorded during the final remeasurement. The quadrats were arranged in five transects of 20 contiguous quadrats at each harvest block, with the transects perpendicular to the direction of harvest equipment traffic.

\section{Analyses}

Black spruce was the predominant species at all study locations, so analyses were directed at this species. After 17 to 20 years, it was no longer possible to reliably determine if trees originated from advance regeneration, from broadcast seeding, or from post-harvest natural recruitment, so analyses were carried out on all black spruce trees.

Response variables included black spruce stem density and stocking (\% of $4-\mathrm{m}^{2}$ quadrats containing at least one stem), stand basal area, and mean height of the tallest trees on stocked quadrats.

In the broadcast seeding study, seeding rate effects were examined using analysis of variance for a randomised complete block design. A planned contrast was used to test for differences between control and seeded treatments, and a test for a linear trend with seeding rate was carried out.

In the protection of advance regeneration study, the effect of harvest method was examined using analysis of variance for a completely randomised design. As noted previously, however, treatments were not assigned randomly to harvest blocks, so the possibility cannot be excluded that harvest treatments and treatment block characteristics were confounded.

M orisita's index ( $\left.I_{d}\right)$ (Hurlbert 1990) was used to test for aggregation of black spruce stems. The index was calculated from:

$$
I_{d}=n \frac{\Sigma X^{2}-N}{N(N-1)}
$$

where $n=$ the number of quadrats, $X=$ the number of stems on a quadrat, and $N=$ the total number of stems on 
Table 1. Twentieth-year black spruce stocking $\left(\%, 4-\mathrm{m}^{2}\right.$ basis) at four broadcast seeding experiments

\begin{tabular}{|c|c|c|c|c|c|c|c|c|c|}
\hline & \multicolumn{4}{|c|}{ Seeding rate (viable seeds ha-1) } & \multirow[b]{2}{*}{ MSE } & \multirow[b]{2}{*}{$\mathbf{F}$} & \multirow[b]{2}{*}{$P>F$} & \multirow{2}{*}{$\begin{array}{c}\mathrm{P}>|\mathrm{T}| \text { in control vs. } \\
\text { seeded contrast }\end{array}$} & \multirow{2}{*}{$\begin{array}{l}\mathrm{P}>|\mathrm{T}| \text { for } \\
\text { linear trend }\end{array}$} \\
\hline & 0 & 50000 & 100000 & 150000 & & & & & \\
\hline \multicolumn{10}{|l|}{ Adanac } \\
\hline All stems & 78.3 & 86.7 & 83.3 & 78.3 & 277.1 & 0.18 & 0.91 & 0.70 & 0.94 \\
\hline Stems $>1.3 \mathrm{~m}$ tall & 63.3 & 75.0 & 73.3 & 71.7 & 236.8 & 0.34 & 0.80 & 0.37 & 0.59 \\
\hline \multicolumn{10}{|l|}{ Hanna } \\
\hline All stems & 64.0 & 79.0 & 88.0 & 88.0 & 233.9 & 2.19 & 0.16 & 0.041 & 0.042 \\
\hline Stems $>1.3 \mathrm{~m}$ tall & 61.0 & 76.0 & 79.0 & 85.0 & 189.4 & 2.20 & 0.16 & 0.040 & 0.038 \\
\hline \multicolumn{10}{|l|}{ Sangster } \\
\hline All stems & 87.5 & 97.5 & 93.8 & 88.8 & 97.9 & 0.87 & 0.49 & 0.33 & 1.00 \\
\hline Stems $>1.3 \mathrm{~m}$ tall & 73.8 & 91.3 & 81.3 & 82.5 & 162.7 & 1.26 & 0.34 & 0.16 & 0.58 \\
\hline \multicolumn{10}{|l|}{ Williamson } \\
\hline All stems & 58.3 & 83.3 & 70.0 & 76.7 & 80.6 & 4.23 & 0.063 & 0.022 & 0.122 \\
\hline Stems $>1.3 \mathrm{~m}$ tall & 45.0 & 80.0 & 61.7 & 70.0 & 114.6 & 5.75 & 0.033 & 0.012 & 0.087 \\
\hline
\end{tabular}

all quadrats. $I_{d}>1$ indicates aggregated stems; $I_{d}=1$ indicates randomly distributed stems; and $I_{d}<1$ indicates uniformly distributed stems (when $X$ does not vary among quadrats, the value of $I_{d}$ approaches $X /(X-1)$. A $\chi^{2}$ test was used to determine if $I_{d}$ values differed from 1 for each seeding rate at each location in the seeding study ( $n=60$ for Williamson and Adanac, $n=80$ for Sangster, and $n=100$ for Hanna), and for each harvest block in the protection of advance regeneration study $(n=100)$. The $\chi^{2}$ value is a measure of the departure of the variance to mean ratio from 1.0, (Hurlbert 1990), and was computed using:

$$
x^{2}=n \frac{\Sigma X^{2}}{\Sigma X}-\Sigma X
$$

M orisita's index varies with quadrat size, so results of this analysis are applicable to the $4-\mathrm{m}^{2}$ scale.

Aggregation was further examined by comparing observed stocking on 4- $\mathrm{m}^{2}$ quadrats with stocking determined from the assumption of a Poisson (random) distribution:

$$
\mathrm{S}=1-\exp (-\mathrm{u})
$$

where $S$ is the stocking proportion, and $u$ is the mean number of stems on a quadrat.

\section{Results \\ Broadcast seeding}

Seeding rate had a significant effect on $20^{\text {th }}$ year black spruce stocking at one of the four experimental locations, and contrasts of seeded vs. unseeded stocking were significant at two locations (Table 1 ). A linear relationship between stocking and seeding rate was significant at one location, and there was some evidence of a significant relationship at a second location (Williamson). Stocking values for stems > $1.3 \mathrm{~m}$ tall were generally high, ranging from 45 to $91 \%$, and averaging $73 \%$.
At two of the experimental locations, seeding rate had a significant effect on $20^{\text {th }}$ year black spruce stem density. At these locations, contrasts of seeded vs. unseeded density were significant, and the linear relationships of density to seeding rate were significant (Table 2). Density of stems > $1.3 \mathrm{~m}$ tall averaged $7758 \mathrm{stems} \mathrm{ha-1}^{-1}$, and ranged from 2583 to 14438 stems ha-1 $^{-1}$, at the lowest and lowest-but-one seeding rates, respectively.

Seeding rate had a significant effect on stand basal area at one of the experimental locations; the seeded vs. unseeded contrast and the linear relationship of basal area to seeding rate were significant here as well (Table 3 ). Black spruce basal area after 20 growing seasons averaged $6.1 \mathrm{~m}^{2} \mathrm{ha}^{-1}$ and ranged from 0.67 to $11.62 \mathrm{~m}^{2} \mathrm{ha}^{-1}$.

The mean height of the tallest tree per quadrat at age 20, averaged over all locations, was $3.3 \mathrm{~m}$, and the change in this height from age 10 to 20 was $22.5 \mathrm{~cm} \mathrm{yr}^{-1}$ (Table 4). Nearly half of black spruce stems were still less than $1.3 \mathrm{~m}$ tall 20 years after treatment (Table 1 ).

Changes in black spruce stem density from age 2 to 20 were unrelated to seeding rate, except at Williamson (Table 2), where density change was positive at low seeding rates and negative at high seeding rates. Over all four locations, stem density increased by an average of 1379 stems ha-1 $^{-1}$ from age 2 to 20 . These changes were minor compared with total stem density (Fig. 1).

\section{Protection of advance regeneration}

The effect of harvest method on black spruce density, stocking or basal area was not statistically significant 17 to 19 years after harvest (Table 5). For all treatments, stem density (all sizes) averaged 11532 stems ha- $^{-1}$, and density of stems $>1.3 \mathrm{~m}$ tall averaged 4704 stems ha-1. Stocking of all black spruce stems averaged $79 \%$ and stocking of black spruce stems $>1.3 \mathrm{~m}$ tall averaged $62 \%$.

Stocking ( $4 \mathrm{~m}^{2}$ basis) and density of black spruce declined sharply after harvest, but increased gradually thereafter, with the surviving advance regeneration augmented by an influx of black spruce established from seed (Fig. 2). 
Table 2. Twentieth-year black spruce density (stems ha-1) at four broadcast seeding experiments

\begin{tabular}{|c|c|c|c|c|c|c|c|c|c|}
\hline & \multicolumn{4}{|c|}{ Seeding rate (viable seeds ha-1 $^{-1}$ ) } & \multirow[b]{2}{*}{ MSE } & \multirow[b]{2}{*}{$\mathbf{F}$} & \multirow[b]{2}{*}{$P>F$} & \multirow{2}{*}{$\begin{array}{c}P>|T| \text { in control vs. } \\
\text { seeded contrast }\end{array}$} & \multirow{2}{*}{$\begin{array}{l}\mathrm{P}>|\mathrm{T}| \text { for } \\
\text { linear trend }\end{array}$} \\
\hline & 0 & 50000 & 100000 & 150000 & & & & & \\
\hline \multicolumn{10}{|l|}{ Adanac } \\
\hline $\begin{array}{l}\text { All stems } \\
\text { Change since vear } 2\end{array}$ & 9208 & 14375 & 13292 & 18667 & $5.82 \times 10^{7}$ & 0.78 & 0.55 & 0.27 & 0.21 \\
\hline all stems & 1083 & 958 & 3833 & 833 & $800390^{6}$ & 0.78 & 0.55 & 0.69 & 0.78 \\
\hline Stems $>1.3 \mathrm{~m}$ tall & 4538 & 7083 & 6333 & 7583 & $5.49 \times 10^{7}$ & 0.56 & 0.66 & 0.28 & 0.33 \\
\hline \multicolumn{10}{|l|}{ Hanna } \\
\hline All stems & 7525 & 11250 & 15600 & 16450 & $1.78 \times 10^{7}$ & 3.84 & 0.051 & 0.02 & 0.009 \\
\hline $\begin{array}{l}\text { Change since year 2, } \\
\text { all stems }\end{array}$ & 2000 & 3950 & 2750 & 2175 & $1.49 \times 10^{7}$ & 0.21 & 0.89 & 0.68 & 0.94 \\
\hline Stems $>1.3 \mathrm{~m}$ tall & 5675 & 7650 & 9125 & 11100 & $6.00 \times 10^{6}$ & 3.51 & 0.062 & 0.031 & 0.01 \\
\hline \multicolumn{10}{|l|}{ Sangster } \\
\hline All stems & 21781 & 26594 & 22750 & 24313 & $6.90 \times 10^{7}$ & 0.26 & 0.86 & 0.58 & 0.84 \\
\hline $\begin{array}{l}\text { Change since year 2, } \\
\text { all stems }\end{array}$ & 1656 & -125 & -281 & 563 & $1.91 \times 10^{7}$ & 0.16 & 0.92 & 0.54 & 0.74 \\
\hline Stems $>1.3 \mathrm{~m}$ tall & 11344 & 14438 & 9375 & 10594 & $1.31 \times 10^{7}$ & 1.43 & 0.30 & 0.95 & 0.39 \\
\hline \multicolumn{10}{|l|}{ Williamson } \\
\hline $\begin{array}{l}\text { All stems } \\
\text { Change since year } 2,\end{array}$ & 4292 & 8833 & 5375 & 11667 & $2.51 \times 10^{6}$ & 13.52 & 0.004 & 0.006 & 0.004 \\
\hline all stems & 3292 & 2042 & -333 & -2333 & 3782552 & 4.97 & 0.046 & 0.036 & 0.009 \\
\hline Stems > $1.3 \mathrm{~m}$ tall & 2583 & 5750 & 3250 & 7708 & $7.61 \times 10^{5}$ & 21.92 & 0.001 & 0.002 & 0.001 \\
\hline
\end{tabular}

Table 3. Twentieth-year black spruce basal area $\left(\mathrm{m}^{2} \mathrm{ha} \mathrm{a}^{-1}\right)$ at four broadcast seeding experiments

\begin{tabular}{|c|c|c|c|c|c|c|c|c|c|}
\hline & \multicolumn{4}{|c|}{ Seeding rate (viable seeds ha-1) } & \multirow[b]{2}{*}{ MSE } & \multirow[b]{2}{*}{$\mathbf{F}$} & \multirow[b]{2}{*}{$P>F$} & \multirow{2}{*}{$\begin{array}{c}P>|T| \text { in control vs. } \\
\text { seeded contrast }\end{array}$} & \multirow{2}{*}{$\begin{array}{l}P>|T| \text { for } \\
\text { linear trend }\end{array}$} \\
\hline & 0 & 50000 & 100000 & 150000 & & & & & \\
\hline Adanac & 3.77 & 6.13 & 5.10 & 4.68 & 8.36 & 0.35 & 0.79 & 0.46 & 0.83 \\
\hline Hanna & 8.35 & 9.42 & 10.51 & 11.62 & 20.42 & 0.39 & 0.77 & 0.43 & 0.31 \\
\hline Sangster & 7.24 & 8.25 & 6.84 & 6.14 & 2.93 & 1.06 & 0.41 & 0.87 & 0.25 \\
\hline Williamson & 0.67 & 3.31 & 1.38 & 4.19 & 0.33 & 24.54 & $<0.001$ & $<0.001$ & 0.001 \\
\hline
\end{tabular}

Table 4. Mean height of tallest tree on 4- $\mathrm{m}^{2}$ quadrats) at four broadcast seeding experiments

\begin{tabular}{lccc}
\hline Location & $\begin{array}{c}\text { Mean height at age 10 } \\
(\mathbf{c m})\end{array}$ & $\begin{array}{c}\text { Mean height at age 20 } \\
(\mathbf{c m})\end{array}$ & $\begin{array}{c}\text { Change in mean height } \\
(\mathbf{c m ~} \mathbf{~ y r}-\mathbf{1})\end{array}$ \\
\hline Adanac & 97 & 323 & 22.6 \\
Hanna & 133 & 413 & 28.0 \\
Sangster & 123 & 333 & 21.0 \\
Williamson & 68 & 252 & 18.4 \\
\hline
\end{tabular}




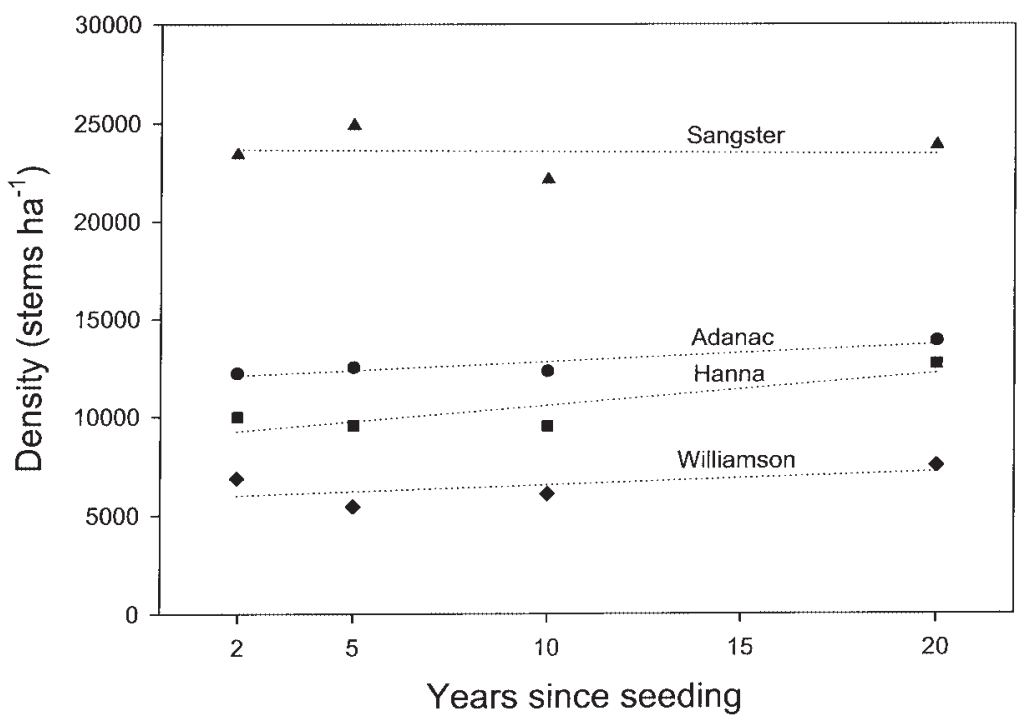

Fig 1. Black spruce density trends after broadcast seeding at four locations (average for all seeding rates).

There was some evidence that the change in black spruce density from one growing season after harvest to 17 to 19 years after harvest was affected by harvest treatment $(p=$ $0.16)$, with less recruitment occurring after winter harvest (Table 5). The mean density change for all harvest blocks considered together was 2373 stems ha-1 $^{-1}$, which was significantly different from 0 ( $p<0.001$, t-test).

Harvest treatment did not affect black spruce basal area, which averaged $2.9 \mathrm{~m}^{2} \mathrm{ha}^{-1}, 17$ to 19 years after harvest.

The mean height of the tallest black spruce stem on 4- $\mathrm{m}^{2}$ quadrats averaged $2.52 \mathrm{~m}, 17$ to 19 years after harvest, and the mean diameter of the largest stem averaged $3.3 \mathrm{~cm}$. The increase in the mean height of the tallest black spruce stem since year 10 averaged $18 \mathrm{~cm} \mathrm{yr}^{-1}$ (Table 6). No effect of harvest method on height or height growth was detected.

\section{Stem aggregation}

M orisita's index $\left(I_{d}\right)$ was significantly greater than 1.0 for all broadcast seeding rates at all locations $(p<0.01)$, with an average value of 1.91 . The value of $I_{d}$ declined with seeding rate ( $p=0.017$, linear regression analysis), averaging 2.34 , $1.85,1.76$ and 1.69 for the $0,50,100$, and 150 thousand seeds per ha rates, respectively. The value of $I_{d}$ was significantly greater than 1.0 for each of the 11 harvest blocks in the regeneration protection study $(p<0.01)$. The average value of $I_{d}$ in this study was 2.12 , with no differences among harvest methods ( $p=0.97$, one-way analysis of variance).

Stocking values were considerably lower than would occur for randomly distributed stems (Fig. 3). Observed stocking values averaged 18 percentage points (broadcast seeding) and 19 percentage points (regeneration protection) lower than stocking for randomly distributed stems at the same density as calculated from a Poisson distribution (equation 3).

\section{Discussion}

The effects of seeding rate on black spruce stocking and density could still be detected after 20 years at two of the experimental locations. At these locations, seeding rate was also a significant influence on stocking and density at ages 2, 5, and 10 (Groot 1996a). The general trend of increasing density with time indicates gradual recruitment of new seedlings and layerings. These increases were minor, however, relative to the total black spruce density.

Black spruce regeneration densities were highest at the locations where seeding rate effects were not detectable. In effect, the high levels of advance regeneration overwhelmed any effects of broadcast seeding, and contributed to high variability of density within and among study locations. These results reinforce previous conclusions that broadcast seeding is unnecessary when sufficient advance regeneration remains after harvest (Groot 1996a). These results are also reflected in current forest practice, since harvest with regeneration protection is applied much more widely than broadcast seeding. Nevertheless, broadcast seeding remains an appropriate treatment for peatland sites that do not have high levels of advance regeneration.

The effects of harvest method on black spruce stocking, density, and basal area were no longer statistically significant 17 to 19 years after harvest. The initial differences between harvest methods in black spruce stocking and density (Groot 1995) declined with time as a result of the post-harvest establishment of new tree seedlings. Snow cover and frozen ground during winter harvesting favour the protection of advance regeneration (Groot 1996b), but the greater soil surface disturbance associated with summer harvesting may have favoured post-harvest establishment in both summer harvest treatments. Although the stocking and density of all black spruce trees were high, the average stocking of trees $>1.3 \mathrm{~m}$ tall (63\%) was moderate, and suggests the sites were not fully occupied.

The results indicate that, on ES11 and ES12 (Taylor et al. 2000), broadcast seeding black spruce and/or harvesting to protect advance regeneration result in high densities ( $>4000$ stems ha-1) of stems taller than $1.3 \mathrm{~m}$ at year 20 . Lower densities of black spruce would likely result on richer peatland sites (ES13p - Black Spruce-Larch-Speckled Alder-Organic Soil - Species Poor, and particularly ES13r - White CedarBlack Spruce - Organic Soil-Species Rich), because of lower cover of Sphagnum seedbeds, lower levels of advance regeneration, and greater levels of shrub and herb competition (Groot 1984). It should be noted that a selection criterion for the harvesting to protect regeneration study location was a high level of advance regeneration; lower post-harvest densi- 


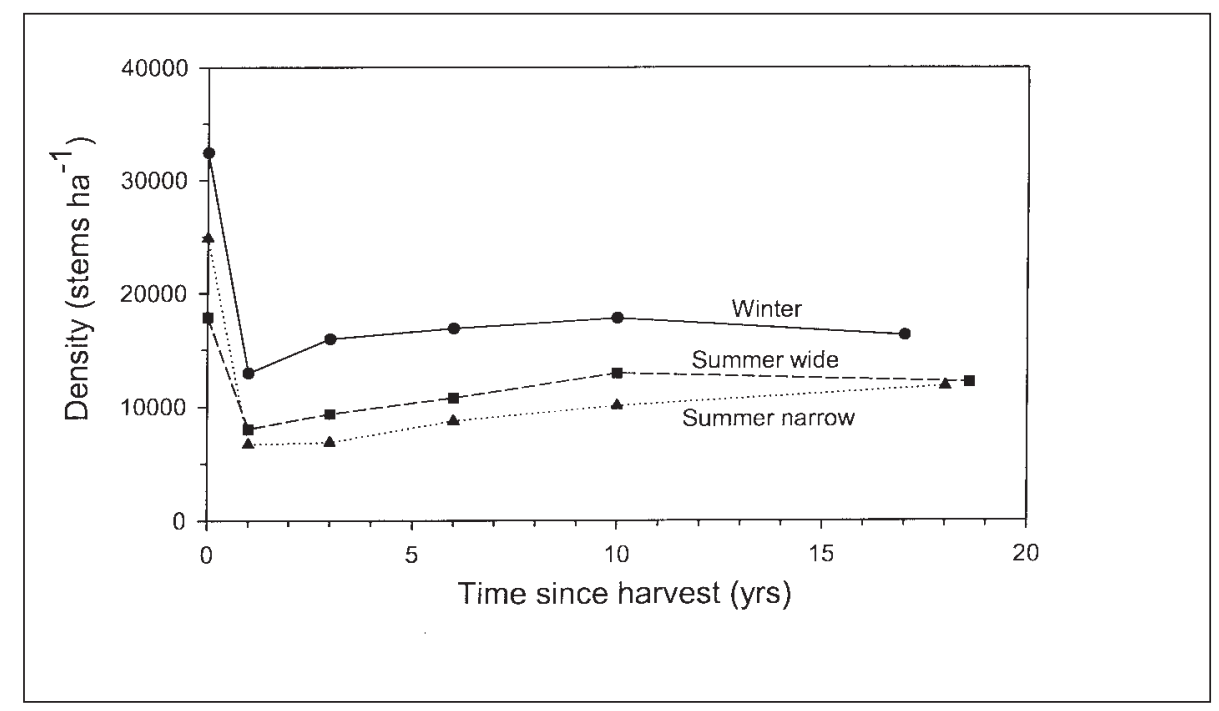

Fig. 2 Black spruce density trends before (year 0) and after harvesting by three methods.

Table 5. Black spruce stem density, stocking and basal area, 17 to 19 years after harvest by three methods

\begin{tabular}{|c|c|c|c|c|c|c|}
\hline & \multicolumn{3}{|c|}{ H arvest Methods } & \multirow[b]{2}{*}{ MSE } & \multirow[b]{2}{*}{$\mathbf{F}$} & \multirow[b]{2}{*}{$p>F$} \\
\hline & Winter & $\begin{array}{l}\text { Summer - } \\
\text { wide tires }\end{array}$ & $\begin{array}{l}\text { Summer - } \\
\text { narrow tires }\end{array}$ & & & \\
\hline Density (stems ha-1), all stems & 13975 & 10697 & 9925 & $1.192 \times 10^{7}$ & 1.21 & 0.35 \\
\hline $\begin{array}{l}\text { Density increase }(\text { stems ha-1) } \\
\text { since age } 1 \text {, all stems }\end{array}$ & 1088 & 2677 & 2333 & 1762294 & 2.35 & 0.16 \\
\hline $\begin{array}{l}\left.\text { Density (stems ha-1 }{ }^{-1}\right) \\
\text { stems }>1.3 \mathrm{~m} \text { tall }\end{array}$ & 5117 & 4178 & 4817 & 1161839 & 0.79 & 0.48 \\
\hline Stocking (\%), all stems & 82 & 81 & 74 & 122.6 & 0.46 & 0.64 \\
\hline Stocking $(\%)$, stems $>1.3 \mathrm{~m}$ tall & 62 & 63 & 62 & 114.1 & 0.03 & 0.97 \\
\hline Basal area $\left(m^{2}\right.$ ha-1) & 2.6 & 3.4 & 2.2 & 4.44 & 0.94 & 0.43 \\
\hline
\end{tabular}

Table 6. Mean height of tallest tree on $4-\mathrm{m}^{2}$ quadrats for three harvest methods

\begin{tabular}{lccc}
\hline & $\begin{array}{c}\text { Mean height at age 10 } \\
(\mathbf{c m})\end{array}$ & $\begin{array}{c}\text { Mean height at age 17-19 } \\
(\mathbf{c m})\end{array}$ & $\begin{array}{c}\text { Change in mean height } \\
\left(\mathbf{c m ~ y r}^{-1}\right)\end{array}$ \\
\hline Winter & 113 & 246 & 18.1 \\
Summer - widetires & 103 & 262 & 18.4 \\
Summer - narrow tires & 110 & 249 & 17.4 \\
\hline
\end{tabular}




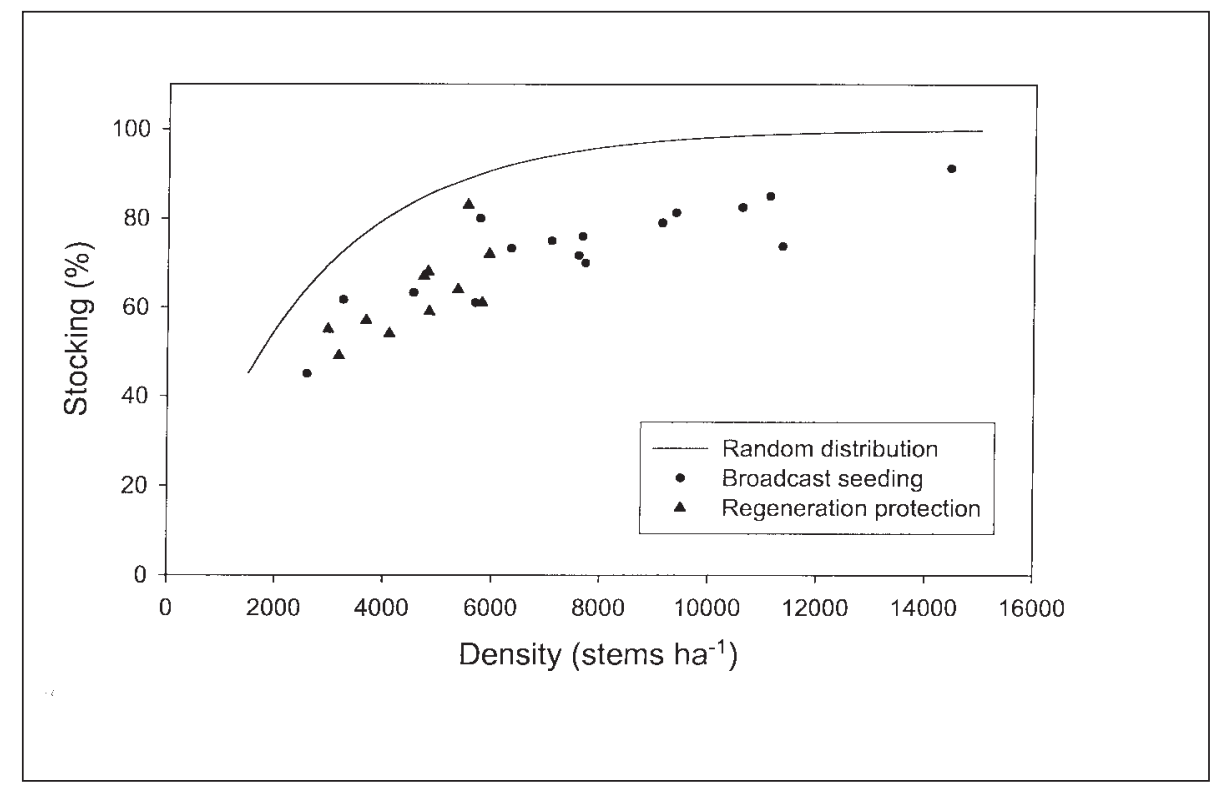

Fig. 3. Observed black spruce stocking (4-m2 basis) versus density for broadcast seeding and regeneration protection treatments, compared with stocking of randomly distributed trees.

Table 7. Comparison of stand characteristics for seeding and harvest methods study areas with Ontario normal yield tables for black spruce (Plonski 1974)

\begin{tabular}{lccc}
\hline & $\begin{array}{c}\text { Basal area } \\
\left(\mathbf{m}^{2} \mathbf{~ h a}\right.\end{array}$ & Height $(\mathbf{m})$ & Height increase $\left({\left.\mathbf{c m ~} \mathbf{~} \mathbf{~}^{-1}\right)}^{-1}\right)$ \\
\hline Seeding study: 20 years & 6.1 & 3.3 & 22.5 \\
Harvest methods study: 17 to 19 years & 3.8 & 2.1 & 18 \\
Plonski site class 2: 20 years & 6.4 & 2.4 & 20 \\
Plonksi site class 3: 20 years & - & 0.9 & 12 \\
\hline
\end{tabular}

ties would almost certainly be the consequence of lower pre harvest advance regeneration levels.

The satisfactory regeneration results on the summer narrow tires regeneration protection treatment were unexpected. These study locations were heavily disturbed during harvesting with an average 14\% cover of deep ruts (Groot 1987), and some evidence of lower post-harvest stocking and density of black spruce (Groot 1995). Nevertheless, a moderate level of post-harvest seedling recruitment and good height growth of seedlings in rutted areas (Groot 1996b) combined to result in an adequately restocked stand.

Although black sprucestem densities were generally high at the study locations, the stems were significantly aggregated at the 4- $\mathrm{m}^{2}$ scale. Black spruce advance regeneration on peatlands is typically of layer origin (Groot 1984), with regeneration clustering around parent trees. Additional aggregation is imposed by timber harvesting, which establishes an alternating pattern of trails and non-trail areas on the harvest area. Furthermore, seedbeds on peatlands occur in a patch mosaic (Groot and Adams 1994), so seed-origin trees are clustered on patches of favourable seedbeds. A con- sequence of the aggregated distribution of stems is more treeless gaps than would occur with a random or uniform distribution of stems. The average stocking level of $62 \%$ observed in the regeneration protection treatments is indicative of substantial gap areas in the regenerated stands. If such gaps are sufficiently persistent and large, they will prevent full occupancy of the site by black spruce trees.

The high proportion of trees less than $1.3 \mathrm{~m}$ tall indicates a heterogeneous size distribution in the regenerating stands. This variation is a result of variability in the size of advance regeneration stems, variability in height growth rates, and variation in establishment dates for post-treatment recruitment. Heterogeneous size distributions are common in older peatland black spruce stands, both of natural and of second-growth origin (Groot and Horton 1994, Lussier et al. 2002).

The basal area, height and height growth of the stands in these studies are similar to black spruce site-class 2 at age 20 in the normal yield tables (Plonski 1974) (Table 7). The stands in the broadcast seeding study had somewhat greater height, basal area and height growth than the stands in the 
harvest methods study. The two-year difference in average stand age between the studies is responsible for at least part of this difference, but possibly site quality was slightly better at the broadcast seeding study sites as well. In the absence of longer-term information, the normal yield tables for siteclass 2 black spruce can be used to represent the development of successfully regenerated peatland stands in forest management planning.

The time required to attain a given stand volume decreases as the size of protected black spruce advance regeneration increases (Pothier et al. 1995, Lussier et al. 2002). Such an effect is not evident for these stands, however, sincetheir development corresponds with theyield tables for natural stands. The average size of protected advance regeneration in these early 1980s operations was evidently not large enough to shift the yield over time relationship.

\section{Acknowledgements and Dedication}

The most recent measurements of these studies were funded in part by Project 130-103 of Ontario's Living Legacy Trust.

This paper is dedicated to the memory of George M arek, whose visit to one of the broadcast seeding study sites and subsequent pointed comments precipitated a "passage of words" among provincial government, federal government and forest industry officials.

\section{References}

Fleming, R.L., A. Groot, M. Adams, L. Van Damme and F. Foreman. 2001. Natural regeneration of conifers. In Wagner, R.G. and S.J. Colombo (eds.). Regenerating the Canadian Forest: Principles and Practice for Ontario. pp. 351-373. Fitzhenry and Whiteside, Markham, ON. 650 p.

Fraser, J.W., V.F. H aavisto, J.K. Jeglum, T.S. Dai and D.W. Smith, D.W. 1976. Black spruce regeneration on strip cuts and clearcuts in the Nipigon and Cochrane areas of Ontario. Can. Dep. Env., Can. For. Serv., Great Lakes Forest Research Centre, Sault Ste. Marie, ON. Info. Rep. 0-X-246. 33 p.

Groot, A. 1984. Stand and site conditions associated with abundance of black spruce advance growth in the Northern Clay Section of Ontario. Can. Dept. Env., Can. For. Serv., Great Lakes Forest Research Centre, Sault Ste. Marie, ON. Info. Rept. O-X-358. 15 p.
Groot, A. 1987. Silvicultural consequences of forest harvesting on peatlands: site damage and slash conditions. Gov't of Canada, Can. For. Serv., Great Lakes Forestry Centre, Sault Ste. Marie, ON. Info. Rept. O-X-384. 20 p.

Groot, A. 1995. Harvesting method affects survival of black spruce advance growth. Northern J. Appl. For. 12: 8-11.

Groot, A. 1996a. Direct seeding black spruce on peatlands: tenthyear results. Nat. Resour. Can., Can. For. Serv., Great Lakes Forestry Centre, Sault Ste. M arie, NODA/NFP Tech. Rep. TR-27. 12 p.

Groot, A. 1996b. Regeneration and surface condition trends following forest harvesting on peatlands. Nat. Resour. Can., Can. For. Serv., Great Lakes Forestry Centre, Sault Ste. Marie, NODA/NFP Tech. Rep. TR-26. 12 p. + append.

Groot, A. and M.J. Adams. 1994. Direct seeding black spruce on peatlands: fifth-year results. For. Chron. 70: 585-592.

Groot, A. and B.J. Horton. 1994. Age and size structure of natural and second growth peatland Picea mariana stands. Can. J. For. Res. 24: 225-233.

Groot, A., J.K. Jeglum and W. Brown. 2001. Natural regeneration of conifers. In Wagner, R.G. and S.J. Colombo (eds.). Regenerating the Canadian Forest: Principles and Practice for Ontario. pp. 375-392. Fitzhenry and Whiteside, Markham, ON. 650 p.

Hurlbert, S.H . 1990. Spatial distribution of the montane unicorn. Oikos 58: 257-271.

Lussier, J.M., H. Morin and R. Gagnon. 2002. Évolution de la structure diamétrale et production ligneuse des pèssieres noires issues de coupe et de feu. Can. J. For. Res. 32: 526-538.

Marek, G.T. 1975. Ecosystem management of black spruce on shallow sites in the Lake Nipigon - Beardmore area. In Black spruce symposium. pp. 195-200. Can. Dep. Environ., Can. For. Serv., Great Lakes Forestry Centre, Symp. Proc. O-P-4. 289 p. + append.

Plonski, W.L. 1974. Normal yield tables (metric). Ontario M inistry of Natural Resources, Division of Forests. 40 p.

Pothier, D., R. Doucet and J. Boily. 1995. The effect of advance regeneration height on future yield of black spruce stands. Can. J. For. Res. 22: 613-621.

Rowe, J.S. 1972. Forest regions of Canada. Can Dep. Environ, Can. For. Serv., Ottawa, ON, Publ. No. 1300. 172 p.

Taylor, K.C., R.W. Arnup, B.G. Merchant, W.J. Parton and J. Nieppola. 2000. A field guide to forest ecosystems of northeastern Ontario. Ontario M inistry of Natural Resources, N ortheast Science and Technology, ON. NEST Field Guide FG-001. 